\title{
OBITUARIES
}

\section{Dr. C. V. Drysdale, C.B., O.B.E.}

Charles Vickery Drysdale, well known for his work on the design of electrical measuring instruments, died at Bexhill on February 7, at the age of eighty-six.

He was born in 1874, his parents being Dr. Charles R. Drysdale and Alice Vickery Drysdale. Like his father, his mother also was medically trained and was well known as Dr. Alice Drysdale Vickery (retaining her maiden name Vickery for professional purposes). She was born at Barnstaple, Devon, in 1846 and was fully trained in medicine and surgery for six years in London and Paris, but even in 1880 the British examining bodies refused to accept women. She went to Dublin, however, and obtained diplomas at King and Queen's College of Physicians certifying her as physician and licentiate in medicine and midwifery.

Dr. Drysdale was educated privately, and at Finsbury Technical College, and the Central Technical College, South Kensington. He was associate head of the Electrical Engineering and Applied Physics Department of the Northampton Institute (London) during 1896-1910.

He became a fellow of the Physical Society in 1898, and was a member of Council 1936-39 and Duddell medallist in 1935. He was also a member of the old Optical Society, of which he became president for 1903-4. A founder fellow of the Institute of Physics in 1920, he served on the Board during 1924-25 and was a vice-president during 1932-36 and editor of the Journal of Scientific Instruments during 1927-28. He was a Fellow of the Royal Society of Edinburgh and a member of the Board of Managers of the Royal Institution (1934-36). In 1920 he delivered the Kelvin Lecture on "Modern Marine Problems" at the Institution of Electrical Engineers, of which he was a member. He was honorary secretary of the Students' Section of the Institution of Electrical Engineers in 1894. He was also a Fellow of the Royal Statistical Society.

In addition to his scientific activities, Dr. Drysdale was a staunch member of the Malthusian League, of which he had been secretary, president and editor of the League's Journal during 1907-16. In 1921 and $1925 \mathrm{he}$ had acted as president of Neo-Malthusian International Conferences in London and New York. $\mathrm{He}$ was a member of the Athenæum Club.

He was well known for his work on optical instruments, and for many years (1902-29) was examiner to the Spectacle Makers' Company. Such a wide range of interests is seldom found in one individual.

During 1910-16 Dr. Drysdale was elosely associated with Mr. H. Tinsley, during part of this period in partnership, as makers of electrical measuring instruments. There he supervised the manufacture of many of his inventions like the a.c. potentiometer and the polyphase wattmeter, which are still made to-day as high-precision instruments. One of his great achievements was the phase-shifting transformer, the basis of servo-mechanisms in use throughout the world.

I first met Dr. Drysdale in January 1918 when he joined the staff of the Admiralty Research Laboratory at Parkeston Quay, Harwich. There he applied his wide knowledge of alternating current theory and electrical instrument design to Service problems. He designed sensitive mechanically tuned a.c. relays of sub-audio frequency, which could be actuated at a considerable range by the electromagnetic field surrounding a cable, lying on the sea bed, carrying alternating current of the same frequency as that of the relay. Afterwards (1919-21), at the Admiralty Experimental Station at Shandon (Gareloch), he made use of this system in the development of a 'leader cable' with visual indication on the bridge, to show the navigating officer the position of his ship, port or starboard, relative to the cable. Certain anomalies in this otherwise simple and useful system were observed, however, and this led Dr. Drysdale to make a very thorough full-scale investigation of the field distribution below and above the sea-surface around a submarine cable carrying alternating current. This work was done in Gareloch (off the Clyde) near Shandon and Rhu. The results of this important investigation, combined with those of theoretical and model-scale experimental work by S. Butterworth at the Admiralty Research Laboratory, Teddington, were published in the Philosophical Transactions of the Royal Society in 1924. This provided an explanation of the ambiguous indications of Dr. Drysdale's experimental leader cable. During the course of this research be became the first superintendent of the Admiralty Research Laboratory, Teddington, in 1921, a post which he held until 1929. In that year he was appointed director of scientific research, Admiralty, in succession to Sir Frank E. Smith. While serving in this post, in which he was in charge of all Admiralty research establishments, he was made a C.B. in 1932. $\mathrm{He}$ retired from Admiralty service in 1934.

He was a prolific writer, having published many original scientific and electrical engineering papers in The Journal of the Institution of Electrical Engineers, The Electrician, The Proceedings of the Physical Society, The Journal of Scientific Instruments, etc., as well as many contributions on Malthusian and NeoMalthusian principles. One of his most important scientific papers is the one to which I have referred (Trans. Roy. Soc.) above. His book on The Foundations of Alternating Current Theory (published in 1910) was based on a series of lectures, extending over five years, which he gave at the Northampton Institute. This was one of the earliest efforts of which I am aware to emphasize the close analogy which exists in the theory of electrical and mechanical oscillations. At the end of the First World War he contributed to a collected work on Mechanical Properties of Fluids, in which he dealt with submarine signalling and the transmission of sound through water. His best-known book, Electrical Measuring Instruments (two vols.), in collaboration with Mr. A. C. Jolley, contains the work of many years study, theoretical and experimental, of the principles of design and operation of all kinds of electrical measuring instruments.

Dr. Drysdale lived a very full and energetic life, having a wide range of interests. He always took a great delight in seeing his theoretical deductions verified by an experiment. I remember him, however, 
working on an experiment at the Royal Institution, after his retirement from the Admiralty, to demonstrate that the basis of Einstein's theory of relativity was wrong. At the time of his death he was busy writing another book.

In 1898 he married Bessie Ingram Edwards, who died some years ago. They had one daughter, Eva, who died young, and an adopted son, Eric, who is married and lives in South America.

\section{A. B. WoOD}

\section{Prof. A. H. Cox}

The death of Prof. A. Hubert Cox on February 14, 1961, will be sadly mourned by his many students dispersed all over the world and by geologists in Britain and in Canada. After graduating at the University of Birmingham as a chemist, he studied in Strasbourg where he carried out research work on benzenoid compounds and a great variety of other chemical problems.

During the First World War he became engaged on chemical work of great national importance which ultimately caused him to turn from chemistry to mineralogy and finally to stratigraphic and structural geology. Even prior to becoming professor of geology in the University College of South Wales and Monmouthshire, he had carried out important research work on the Ordovician rocks of Wales. His enthusiasm and energy in tackling the difficult and unknown structure and petrology of Cader Idris became symbolic of his future interast in the geology of the Principality. His name will always be associated with the pioneering work that was done in the early part of this century on theolder rocks of Wales and, in particular, with the establishment of type-sections in Pembrokeshire. Conscious of the contribution which geology and geologists should make to industry, he devoted himself to the problems connected with the development of the coals of South Wales. He was among the first to apply geophysical methods to the determination of geological structures, and his use of rasistivity measurements in the Coal Measures became the basis for a great deal of the modern work in this field of geophysics. He was among the first to illustrate how resistivity methods could be used to locate water-saturated strata in the Coal Measures and how those could be used in the development of the mines. His earlier training as a chemist made him singularly able to conduct investigations into the incidence of silicosis, as it was then called, among the miners of the South Wales coalfield. So tireless were his efforts to secure knowledge of the environmental factors concerning this disease among miners and so conscious was he of his duty as a scientist to the community, that his work became responsible for the complete ravision of the pensions schemes for miners afflicted with pneumoconiosis.

Likewise, his contribution to the welfare and the development of the University College, Cardiff, will always be remembered and revered, and very specially by the many students entrusted to his care. Through many of these he was able to make profound contribu. tions to the understanding of the structure of the Canadian Rockies and more especially to that of the Selkirk Mountains. His arduous work helped to establish the location of several important reserves of gold and silver and he can be said to have been among the pioneers of the scientific development of the mineral resources of Western Canada.

W. D. Evans

\section{NEWS and VIEWS}

Director of the National Lending Library for Science and Technology: Dr. D. J. Urquhart THE Department of Scientific and Industrial Research recently announced that Dr. D. J. Urquhart has been appointed the first director of the National Lending Library for Science and Technology at Boston Spa, Yorks. Dr. Urquhart was educated at Barnard Castle School and the University of Sheffield where he graduated in 1931 with an honours degree in physics. Afterwards he obtained a Ph.D. in the Metallurgical Faculty at Sheffield, and then he worked in the research department of a steel works. In 1938 , Dr. Urquhart was appointed to the staff of the Science Museum Library. During the War he was at the Ministry of Supply, engaged mainly in the technical administration of armaments inspection. In 1948, he was transferred to the Information and Intelligence Division of the Department of Seientific and Industrial Research, where he was responsible for the reorganization of the Headquarters Library and Records and carried out a number of surveys of the use made of technical literature in different industrial centres. In November 1956 he became responsible for planning the National Lending Library. Since then he has been wholly concerned with the planning and creation of the new library, which has included the introduction of Britain's
Russian translating programme in co-operation with the National Science Foundation's programme in the United States. Dr. Urquhart writes frequently on library and technical information topics. In recent years he has made a number of notable contributions in this field, starting with a paper he raad to the University and Research Section of the Library Association in January 1957 on the new National Lending Library. It was in this paper that Dr. Urquhart estimated the size and requirements of the National Lending Library, and forecast the huge growth of Chinese scientific literature in the future. He dealt with this subject again in a paper to the Library Association last year. In 1958, at the International Conference on Scientific Information in Washington, he reported the results of an interesting analysis of the pattern of borrowing from the Science Museum Library which has served to guide the acquisition policy of the National Lending Library.

\section{Civil Engineering at Swansea :}

Prof. O. C. Zienkiewicz

Dr. O. C. ZIEnkrewiCz, who has been appointed to succeed Prof. B. G. Neal (see Nature, 188,$896 ; 1960$ ) in the chair of civil engineering at the University College of Swansea, will bring to his now appointment experience of both British and American universities. 